into areas where they do not want to go," says Burke, adding that many view cloning as "an invasion of personality" and "a Pandora's box with unpredictable consequences". $\mathrm{He}$ believes scientists need to first let the public become accustomed to cloning of animals. "We should not move on [research into] human cloning; society is not ready for it."

Jones says: "The public is not frightened of progress but of rapid progress." He points out that the once controversial techniques of test-tube babies and organ transplants are now widely accepted. The job of ethics committees, he says, is to act as a "brake", slowing the application of technology to a speed acceptable to the public.

Several observers predict that human cloning will shift from being "totally unacceptable" to being permitted, say, for tissue culture or even treating some forms of infertility. Experience suggests that public opinion may support a mother who wishes to clone her dead child, says one scientist. "It is possible that after a long debate society might accept cloning under controlled conditions," says Burke.

Many observers predict that the passionate debate of the past few days is likely to subside relatively rapidly. The cacophony of calls for a ban on all research on human cloning looks set to be followed by a realization that, in a democracy, legislators usually need good reasons for restricting scientific progress.

\section{Does cloning mean new ethics?}

Beyond concern that science is moving so quickly that society cannot keep up, the arguments of proponents of a ban on animal and/or human cloning have generally not gone much deeper than vague assertions that these pose "new ethical problems" or are "contrary to nature". The various ethics committees now convened on cloning should bring some welcome clarification.

The 'contrary to nature' argument fails to take into account "the reality that man has long manipulated animals to his own ends", says one observer. Jones says: "I felt like asking Clinton; do you eat lamb chops?"

The widely held philosophical argument that human cloning attacks the fundamental principle of the 'human dignity' of individuals is also challenged by some. This claim, they argue, amounts to an apology for genetic determinism, in that it implicitly ignores the influence of 'nurture' on personality. Identical twins are given two souls by the church, and two votes by the state - not one.

Indeed, scientists have strongly emphasized that human clones would not be strictly 'identical', as they would be born a generation apart and experience different environmental influences. A clone of Hitler would not necessarily become a dictator; and a clone of one's father would not actually be one's father, as his relationship would not be a parental one.
According to Burke, the frequency with which such reservations have been expressed in the debate about cloning itself marks a significant shift away from the recent trend towards genetic determinism. "It has shifted the balance back towards the nurture end of the nature-versus-nurture debate."

Others argue optimistically that society's collective ideological apparatus is sufficient to prevent abuses of cloning. One widely aired concern is the prospect that human clones might be created as a reserve of spare parts, but nature produces identical human twins, and no one has yet converted one into an organ bank for the other. Humanity would also be unlikely to abandon the benefits of sexual reproduction - genetic diversity and hybrid vigour - in favour of cloning.

What most people seem to agree is that the main risk of human cloning is that it would allow third parties to impose biologi- cal predetermination. They argue that the lottery of heredity affords the best protection against this threat.

But at least one scientist, Richard Dawkins, professor of public understanding of science at the University of Oxford, confesses to a desire to be cloned. "I think it would be mind-bogglingly fascinating to watch a younger edition of myself growing up in the twenty-first century instead of the 1940s."

Indeed, a wider outcome of the debate about cloning is that it has prompted some scientists to warn against what they claim is an increasingly unjustified stigmatization of the potential dangers of genetic research. "I find it astonishing that people complain bitterly about the perceived threat of genetics to human dignity when they see grotesque insults to human dignity all around them which could be changed tomorrow and they do nothing about", says one scientist.

\title{
Putting the lid on Pandora's box of genetics
}

[PARIS \& WASHINGTON] The

United States and the

European Union have both commissioned immediate reviews of the ethics of cloning research.

But it is far from clear what regulations - if any will be imposed on animal cloning, or indeed on research into human cloning. Nor are there any obvious ways of drawing a strict borderline between research in the field that is and is not ethically acceptable.

That the world's legislatures were so unprepared for the advent of cloning can be explained in part by the widespread belief that the ability to clone mammals from adult tissue was a long way off. "Gobsmacked" is how several geneticists describe their reaction to the news.

Both Francis Collins, director of the US National Human Genome Research Institute, and Bruce Alberts, president of the US National Academy of Sciences, concede that they were "totally caught off guard" by last week's news. 'It's hard to get [busy experts] to spend a lot of time on hypothetical scenarios that seem like they're almost certainly not going to come true," says Alberts.

In the United States, research into cloning could currently proceed in the unregulated private sector of reproductive medicine. One option that the National

Bioethics Advisory

Commission will consider is whether curbs on this sector are needed. Public research agencies funded by the Department of Health and Human Services - including, most prominently, the National Institutes of Health could not carry out cloning research as it would fall under an existing ban on federal funding for human embryo research. But technically, if not politically, research could currrently be funded by other government departments.

A New York state senator, John Marchi (Republican, Staten Island), has introduced a bill in that state's legislature that would make human cloning a crime carrying a three- to seven-year prison sentence. The bill would also give the New York State Department of Health regulatory authority over research on animal cloning. But the governor of New York, George Pataki (Republican), said it was "just too soon" for politicians to jump into the fray.

The European Commission's advisory group on biotechnology will carry out a broad review of genetics research and see whether regulations need tightening, according to its chairwoman, Noëlle Lenoir. She is a member of the French Constitutional Council and chairwoman of Unesco's International Bioethics

Commission. Work on human cloning is already forbidden in research funded by the European Union, she points out.

Jürgen Rüttgers,

Germany's science minister, has sought to reassure the German population, pointing out that the cloning of people is strictly forbidden under the country's 1990 embryo protection act. Meanwhile, Ernst Benda, a former president of the German Constitutional Court has criticized Unesco's draft convention on bioethics for failing to explicitly forbid human cloning.

The House of Commons Select Committee on Science and Technology has agreed to meet to discuss whether existing UK legislation contains loopholes that might allow human cloning (see Nature 385, 767; 1997). The French national bioethics committee is to study the Country's bioethics laws which are considered to ban cloning, but do not do so explicitly.

D.B. \& M.W. 